Penelitian

\title{
Reaksi Transfusi pada Kucing Hipoalbuminemia yang Diinfus dengan Human Serum Albumin 20\%
}

\author{
(Reaction of Transfusion in Hypoalbuminemic Cats Infused \\ with 20\% Human Serum Albumin)
}

\section{Putu Devi Jayanti', Julitha Dewitri Merthayasa', Soedarmanto Indarjulianto², Anggi Novita Sari³, Dwi Cahyo Budi Setiawan ${ }^{4}$, Agustina Dwi Wijayanti ${ }^{4}$}

\author{
${ }^{1}$ Program Studi Sain Veteriner, Fakultas Kedokteran Hewan, Universitas Gadjah Mada \\ ${ }^{2}$ Departemen Ilmu Penyakit Dalam, Fakultas Kedokteran Hewan, Universitas Gadjah Mada \\ ${ }^{3}$ Mahasiswa Fakultas Kedokteran Hewan, Universitas Gadjah Mada \\ ${ }^{4}$ Laboratorium Farmakologi, Fakultas Kedokteran Hewan, Universitas Gadjah Mada, \\ Fakultas Kedokteran Hewan UGM, JI. Fauna No. 2, Karangmalang, Yogyakarta 55281 \\ *Penulis untuk korespondensi: tinabdy@ugm.ac.id \\ Diterima 8 Maret 2018, 23 September 2018
}

\begin{abstract}
ABSTRAK
Hipoalbuminemia umum terjadi pada hewan sakit yang dapat memperburuk kesembuhan beberapa penyakit karena berkorelasi dengan peningkatan morbiditas dan mortalitas. Infus human serum albumin 20\% digunakan sebagai terapi suportif pada kasus hipoalbuminemia. Penelitian ini bertujuan untuk mengetahui reaksi transfusi yang dihasilkan pada kucing hipoalbuminemia yang diinfus human serum albumin 20\% berdasarkan hasil pemeriksaan fisik dan pengamatan tanda klinis. Hewan yang digunakan dalam penelitian ini adalah kucing berbagai ras, dewasa umur 1-3 tahun, jantan maupun betina dengan kondisi hipoalbuminemia. Dilakukan pengambilan darah sebelum terapi dan penghitungan defisit kadar albumin. Larutan human serum albumin 20\% diberikan melalui infus intravena dengan dosis tunggal selama 4-5 jam. Volume albumin yang diberikan dihitung menggunakan modifikasi rumus dan metode Hackner. Data hasil pengamatan reaksi transfusi yang dihasilkan pada kucing hipoalbuminemia dianalisis secara deskriptif. Pada kucing terjadi reaksi transfusi segera yang meliputi terjadinya peningkatan suhu rektal, aritmia jantung, ritme napas ireguler, tremor, dan kelemahan, yang umumnya teramati pada 1 jam pertama selama infus. Sementara itu, reaksi transfusi tertunda meliputi penurunan nafsu makan, kelemahan, edema perifer, erithema, kepincangan, ultikaria, lesi kulit, diare, dan inflamasi perivaskuler. Penelitian ini menunjukkan bahwa aplikasi infus human serum albumin $20 \%$ menghasilkan reaksi transfusi segera maupun tertunda yang teramati pada 8 ekor kucing. Tidak ditemui adanya reaksi merugikan yang parah selama aplikasi infus human serum albumin $20 \%$.
\end{abstract}

Kata kunci: kucing, hipoalbuminemia, reaksi transfusi, serum albumin manusia

\begin{abstract}
Hypoalbuminemia is a fairly common occurrence in many critically ill animals and can negatively affect the prognosis of some diseases because it correlates with the increased morbidity and mortality. Infusion of $20 \%$ human serum albumin was used as a supportive therapy in cases of hypoalbuminemia. The aim of this research is to determine the transfusion reactions produced in hypoalbuminemic cats infused with $20 \%$ human serum albumin based on the results of physical examination and clinical signs observation. Animals used in this study were cats of various breeds, adults with age ranged 1-3 years old, males and females with hypoalbuminemia conditions. Blood sampling was performed before therapy and counting the deficit of albumin levels. The $20 \%$ human serum albumin solution was administered by intravenous infusion with a single dose for 4-5 hours. The albumin volume was calculated and administered according to the formula and method of Hackner. The results of the observed transfusion reactions produced by the hypoalbuminemic cats were analyzed descriptively. The immediate transfusion reaction involved an increase in rectal temperature, cardiac arrhythmias, irregular breathing rhythm, tremors, and lethargy, which were generally observed in the first hour during infusion. Meanwhile, the delayed transfusion reactions included the decreased appetite, weakness, peripheral edema, erythema, lameness, ulticaria, skin lesions, diarrhea, and perivascular inflammation. This research showed that application of infusion of $20 \%$ human serum albumin resulted in immediate and delayed transfusion reactions observed in 8 cats. No severe adverse reactions were found during infusion of $20 \%$ human serum albumin.

Keywords: cat, hypoalbuminemia, transfusion reaction, human serum albumin
\end{abstract}




\section{PENDAHULUAN}

Hipoalbuminemia merupakan komplikasi umum pada sejumlah penyakit yang memperburuk prognosis kesembuhan beberapa penyakit karena berkorelasi dengan peningkatan morbiditas dan mortalitas (Throop et al., 2004; Call, 2005; Savigny \& Macintire, 2006; Cohn et al., 2007; Powell et al., 2013; Horowitz et al.,2015). Hipoalbuminemia dapat disebabkan oleh berbagai faktor, seperti terjadinya penurunan sintesis albumin, peningkatan kehilangan albumin dalam tubuh, redistribusi albumin ke luar ruang intravaskuler, maupun terjadinya pengenceran albumin di dalam ruang intravaskuler. Hipoalbuminemia pada hewan sering kali disebabkan oleh penyebab multifaktorial (Throop et al., 2004).

Terapi kausatif dan simptomatik penyebab penyakit penting dilakukan untuk menanggulangi kondisi hipoalbuminemia. Tindakan suportif dan pemberian koloid sintetis dapat memperbaiki kondisi klinis pasien, tetapi tidak dapat menyediakan beberapa fungsi penting albumin (Throop et al., 2004). Oleh karena itu, albumin sering kali diberikan sebagai terapi suportif (Savigny \& Macintire, 2006; Cohn et al., 2007; Vigano et al., 2010). Terbatasnya ketersediaan feline albumin secara komersial menyebabkan human serum albumin mulai diaplikasikan pada pasien hewan (Horowitz et al., 2015; Vigano et al., 2010; Mathews, 2008; Cohn et al., 2007).

Human serum albumin merupakan larutan albumin pekat yang berasal dari darah manusia, yang setelah diproses mengandung setidaknya 96\% albumin tanpa faktor pembeku (Call, 2005). Larutan tersebut berfungsi sebagai protein pembawa untuk steroid, asam lemak, dan hormon tiroid, yang memainkan peran penting dalam menstabilkan volume cairan ekstraseluler (He et al., 2011). Human serum albumin (HSA) merupakan xenoprotein untuk hewan yang diproduksi dari gabungan plasma manusia melalui proses ultrafiltrasi dan sterilisasi panas (Hackner, 2012). Meskipun albumin terkandung dalam plasma hewan dan manusia, terdapat perbedaan antara molekul albumin yang ditemukan di berbagai spesies (Cohn et al., 2007; Chruszcz et al., 2013). Hal tersebut memungkinkan timbulnya reaksi imunologis yang selanjutnya menyebabkan reaksi merugikan setelah pemberian atau paparan berulang (Hackner, 2012). Berdasarkan latar belakang di atas, penelitian ini dilakukan untuk mengetahui reaksi transfusi yang dihasilkan oleh kucing hipoalbuminemia yang diinfus dengan HSA 20\% berdasarkan pengamatan pemeriksaan fisik yang meliputi suhu rektal, frekuensi jantung, frekuensi napas, dan gejala klinis pascaterapi.

\section{BAHAN DAN METODE}

\section{Pengenceran Larutan HSA 20\%}

Dosis larutan HSA diberikan kepada pasien kucing hipoalbuminemia berdasarkan defisit albumin setiap individu. Pemberian larutan dihitung dengan menggunakan rumus yang diturunkan dari penelitian Hackner (2012).

Larutan albumin $=10 \times$ (kadar albumin target kadar albumin pasien) $\times$ BB $\times 0,3$

Pada penelitian ini digunakan HSA 20\% Behring, low salt, yang diproduksi oleh CSL Behring $\mathrm{GmbH}$, Marburg, Jerman dan diimpor oleh PT. Dexa Medica, Palembang, Indonesia. Sediaan HSA 20\% dilarutkan dalam sodium klorida $0,9 \%$ dengan perbandingan 1 : 9 sehingga total volume larutan yang diberikan menjadi 10\% dari larutan albumin yang diberikan. Pengenceran larutan dilakukan pada suhu ruangan (Hackner, 2012; Horowitz et al., 2015; Trow et al., 2008). Mazzaferro et al. (2002) menyatakan bahwa aplikasi koloid natural yang dikombinasi dengan kristaloid dapat membantu mencapai tujuan terapi untuk memperbaiki volume intravaskuler dan tekanan osmotik koloid.

\section{Perlakuan Hewan Coba}

Ford \& Mazzaferro (2006) melaporkan bahwa kadar albumin normal pada kucing dewasa adalah 3,0-4,2 g/dL sehingga pasien dengan kadar albumin di bawah nilai normal dinyatakan mengalami hipoalbuminemia. Sebelum perlakuan, 8 ekor kucing berbagai ras dengan umur dewasa (1-3 tahun), jantan maupun betina dengan kondisi hipoalbuminemia, diobservasi kondisinya melalui pemeriksaan fisik. Selain itu, dilakukan juga penyesuaian pakan dan minimalisasi tingkat stres individu. Pengambilan darah dilakukan melalui vena cephalica yang ditampung dalam tabung EDTA untuk pemeriksaan kadar albumin dan total protein plasma. Pasien kucing yang hipoalbuminemia diterapi infus larutan human serum albumin 20\% dengan dosis tunggal selama 4-6 jam secara intravena melalui vena pusat maupun perifer (Hackner, 2012). Pada penelitian ini, pemberian infus larutan serum albumin manusia $20 \%$ pada pasien kucing hipoalbuminemia menggunakan berukuran $24 \mathrm{G}$ dan infus set dengan faktor tetes 60 tetes/menit. Penentuan laju tetesan infus dihitung dengan rumus sebagai berikut (Anonim, 2014): 
Laju Infus IV (tetes/menit)=

Volume Infus yang diberikan (ml)x Faktor Tetes (tetes/menit) Lama pemberian dalam jam $\times 60$ (menit//am)

\section{Pengamatan Reaksi Transfusi yang Dihasilkan}

Selama pemberian infus larutan HSA 20\% dilakukan pemeriksaan fisik pada menit ke-o hingga menit ke-300 yang meliputi pengukuran suhu rektal, frekuensi jantung, frekuensi napas, dan perubahan fisik. Pengamatan reaksi transfusi yang dihasilkan pada kucing hipoalbuminemia dilakukan pascapemberian infus larutan HSA 20\% berdasarkan pengamatan perubahan fisik dan gejala klinis yang muncul lebih dari 2 jam setelah pemberian infus larutan human serum albumin berakhir hingga minggu ke-4. Pada penelitian Hackner (2012) dilaporkan bahwa terdapat reaksi hipersensitivitas segera maupun reaksi hipersensitivitas tertunda pada hewan terkait dengan aplikasi HSA yang merupakan larutan xenoprotein bagi tubuh hewan. Hal tersebut didukung oleh penelitian Vigano et al. (2010) yang melaporkan bahwa reaksi tranfusi tertunda pada hewan dikaitkan dengan respons terhadap infus human serum albumin yang puncaknya teramati 4-6 minggu setelah terapi.

\section{HASIL}

Hasil penelitian ini menunjukkan bahwa tujuh dari delapan ekor kucing hipoalbuminemia yang diamati menunjukkan reaksi merugikan yang berkembang selama pemberian larutan infus HSA 20\%. Reaksi merugikan juga diamati pada penga-matan setelah pemberian infus human serum albumin $20 \%$. Ratarata penyelesaian pemberian infus human serum albumin 20\% adalah 4,5 jam (kisaran 3,5 hingga 5,5 jam). Pada penelitian ini diamati terjadinya reaksi transfusi segera dan tertunda. Data reaksi transfusi segera pada kucing hipoalbuminemia yang diterapi infus human serum albumin $20 \%$ dapat dilihat pada Tabel 1. Satu dari delapan ekor kucing diamati mengalami edema perifer dan erithema sebagai reaksi transfusi segera selama pemberian larutan infus human serum albumin 20\% (Gambar 1).

Reaksi transfusi tertunda diamati pada 8 ekor kucing setelah pemberian infus human serum albumin $20 \%$. Data reaksi transfusi tertunda pada kucing hipoalbuminemia yang diterapi infus human serum albumin $20 \%$ dapat dilihat pada Tabel 2. Reaksi transfusi tertunda berupa lesi kulit dan urtikaria berkembang pada 1 dari 8 kucing setelah infus human serum albumin 20\% (Gambar 2).

Tabel 1 Data reaksi transfusi segera pada 8 ekor kucing hipoalbuminemia yang diterapi infus human serum albumin $20 \%$

\begin{tabular}{lcccccc}
\hline \multirow{2}{*}{$\begin{array}{c}\text { Reaksi Transfusi } \\
\text { Segera }\end{array}$} & \multicolumn{7}{c}{ Waktu Terapi Infus HSA 20\% (menit) } \\
\cline { 2 - 7 } & 60 & 120 & 180 & 240 & 300 & 360 \\
\hline Peningkatan Suhu Rektal (PS) & 6 & 4 & 2 & 0 & 0 & 0 \\
Aritmia Jantung (AJ) & 8 & 6 & 3 & 2 & 1 & 0 \\
Ritme Napas Irregular (RNI) & 7 & 6 & 5 & 3 & 2 & 0 \\
Tremor (T) & 2 & 2 & 0 & 0 & 0 & 0 \\
Kelemahan (L) & 7 & 8 & 7 & 6 & 4 & 2 \\
\hline
\end{tabular}

Tabel 2 Data reaksi transfusi tertunda pada 8 kucing hipoalbuminemia yang diterapi infus human serum albumin $20 \%$

\begin{tabular}{llllll}
\hline \multicolumn{1}{c}{ Reaksi Transfusi } & \multicolumn{4}{c}{ Pengamatan Tanda Klinis (Minggu) } \\
\cline { 2 - 5 } \multicolumn{1}{c}{ Tertunda } & 0 & 1 & 2 & 3 & 4 \\
\hline Penurunan Nafsu Makan & 4 & 0 & 0 & 0 & 0 \\
Kelemahan & 2 & 1 & 0 & 0 & 0 \\
Edema Perifer & 1 & 0 & 0 & 0 & 0 \\
Erithema & 4 & 0 & 0 & 0 & 0 \\
Kepincangan & 3 & 1 & 0 & 0 & 0 \\
Urtikaria & 0 & 0 & 1 & 1 & 1 \\
Lesi Kulit & 0 & 0 & 1 & 1 & 1 \\
Diare & 1 & 2 & 0 & 0 & 0 \\
Inflamasi Perivaskuler & 2 & 2 & 0 & 0 & 0 \\
\hline
\end{tabular}



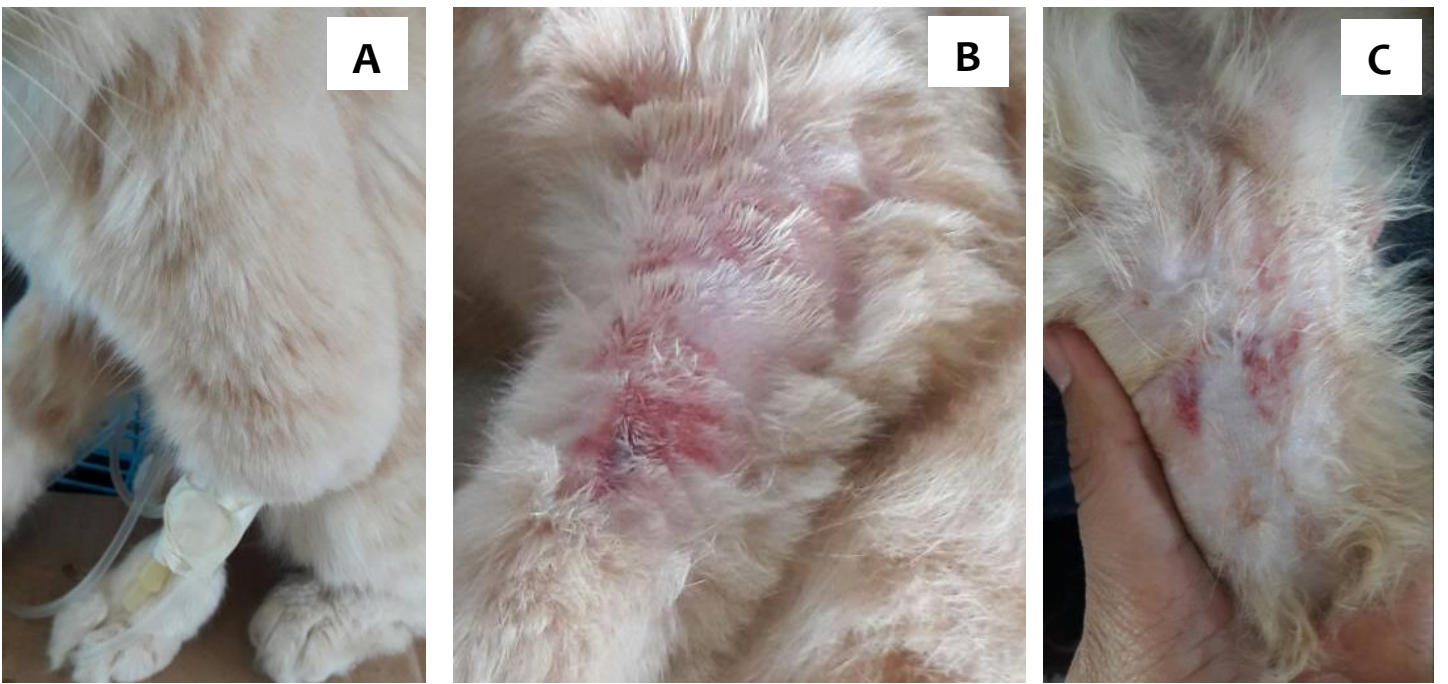

Gambar 1 Reaksi transfusi segera yang muncul pada menit ke-30 teramati terjadinya edema perifer (A) dan pada menit ke-300 teramati terjadinya erithema (B) dari awal aplikasi human serum albumin $20 \%$. Reaksi transfusi tertunda berupa erithema yang teramati pada hari ke-2 setelah infus human serum albumin $20 \%$ (C)
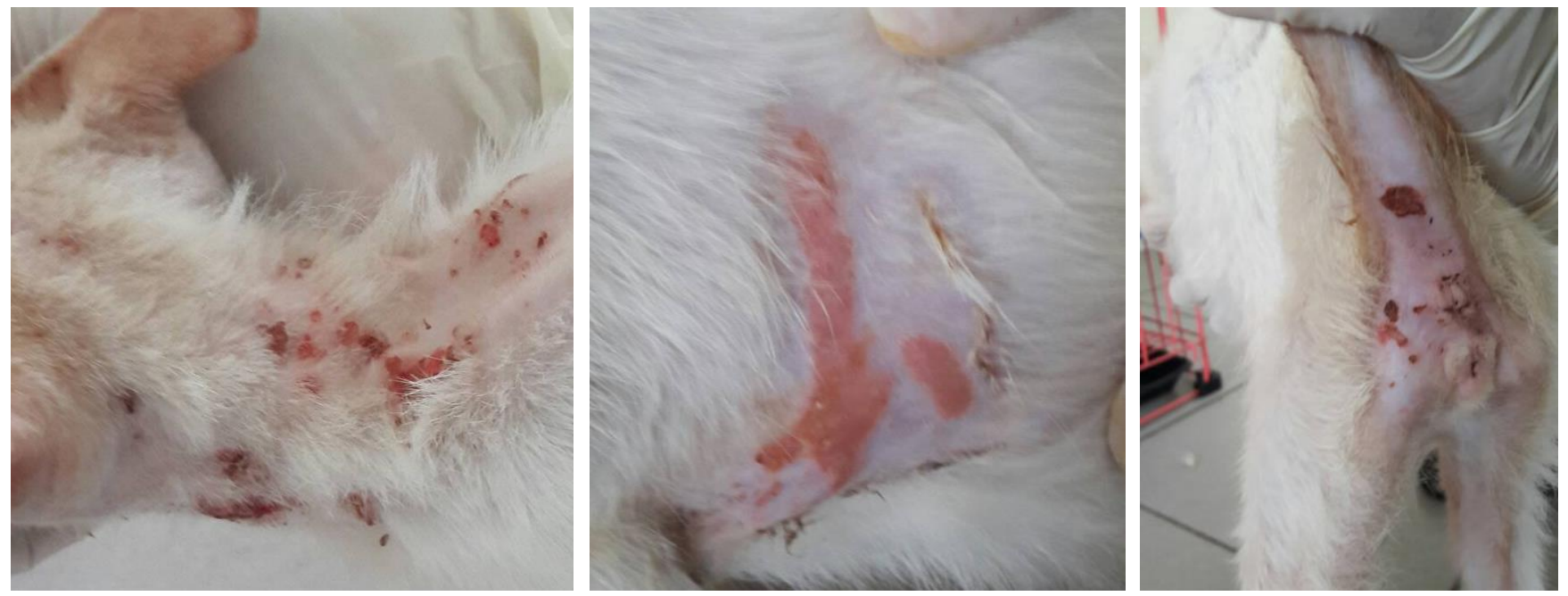

Gambar 2 Reaksi transfusi tertunda pada kucing hipoalbuminemia pada hari ke-13 setelah infus human serum albumin 20\%. Teramati adanya lesi kulit dan urtikaria

\section{PEMBAHASAN}

Transfusi darah adalah proses pemindahan darah atau produk darah dari donor ke resipien, yang ditandai dengan adanya transplantasi jaringan walaupun dalam bentuk cair sehingga memungkinkan timbulnya reaksi penolakan pada tubuh resipien. Berdasarkan waktu timbulnya gejala, reaksi trans-fusi dibedakan menjadi reaksi transfusi segera dan yang tertunda (Triwibowo, 1997). Terapi infus albumin dapat menghasilkan efek mengun-tungkan dan efek samping bila diindikasikan secara intravena (Raoufinia et al., 2016). Hal tersebut didukung oleh Cohn et al. (2007) dan Chruszcz et al. (2013) yang menyatakan bahwa meskipun albumin terkandung dalam plasma hewan dan manusia, terdapat perbedaan antara molekul albumin yang ditemukan di berbagai spesies. Hal tersebut memungkinkan timbulnya reaksi imunologis yang selanjutnya menyebabkan reaksi merugikan setelah pemberian atau paparan berulang HSA (Hackner, 2012).

Pasien kucing yang diinfus HSA 20\% pada penelitian ini mengalami perubahan klinis berupa hipotermia, hipertermia, takikardia, bradikardia, ritme napas yang tidak teratur, dan kelemahan pada menit ke-15 awal pemberian. Empat dari delapan pasien kucing mengalami reaksi merugikan berupa tremor yang muncul pada menit ke-30 dan umumnya kembali normal pada menit ke-120. Hasil tersebut menunjukkan bahwa aplikasi HSA 20\% me- 
lalui infus intravena pada 8 kucing hipoalbuminemia menimbulkan reaksi transfusi segera berupa terjadinya pening-katan suhu rektal, aritmia jantung, ritme napas yang tidak teratur, tremor, dan kelemahan. Hasil ini didukung oleh Trow et al. (2008) yang juga melaporkan bahwa terjadi komplikasi ringan sebagai reaksi transfusi se-gera berupa peningkatan laju pernapasan, peningkatan denyut jantung, kenaikan suhu, edema perifer, dan aritmia ventrikel. Hal serupa dilaporkan oleh Vigano et al. (2010) yang juga menyatakan bahwa reaksi hipersensitivitas segera yang ditimbulkan selama pemberian HSA meliputi syok anafilaksis, henti jantung, aritmia ventrikel, edema pulmonari, gagal ginjal akut, urtikaria, pruritus edema perifer, hipertermia, diare, vomitus, tremor, dan hipotensi.

Gales dan Erstad (1993) melaporkan timbulnya reaksi anafilaktoid berupa munculnya ruam, demam, takikardia, hipotensi, mual, dan syok pada pasien yang diterapi HSA. Reaksi anafilaktoid dapat dipicu oleh agregasi atau denaturasi molekul albumin. Sodium caprylate merupakan stabilisator yang digunakan dalam larutan komersil HSA, yang secara imunologis dapat mengubah larutan serum albumin dan mengendapkan reaksi anafilaktoid. Pasien dengan defisiensi imunoglobulin A (IgA) dapat mengalami peningkatan kejadian reaksi hipersensitivitas berdasarkan aplikasi human serum albumin. Triwibowo (1997) menyatakan bahwa reaksi anafilaktoid muncul akibat adanya reaksi imunoglobulin $G(\lg G)$ anti $\lg G$, imunoglobulin $M$ ( $\lg M)$ anti $\lg M$, atau human albumin.

Reaksi transfusi segera pada penelitian ini mulai terjadi pada menit ke-15 hingga menit ke-120. Akan tetapi, pada beberapa kucing berlanjut hingga terapi HSA 20\% berakhir. Vigano et al. (2010) melaporkan bahwa reaksi transfusi segera terjadi dalam 15-30 menit dari awal aplikasi infus yang mengandung albumin. Secara eksperimental tanda klinis reaksi transfusi segera dapat timbul setelah 2 menit sampai 60 menit, tetapi rata-rata sudah tampak pada 30 menit pertama setelah infus (Triwibowo, 1997).

Reaksi transfusi tertunda pada penelitian ini diamati terjadi mulai pada hari ke-1 hingga minggu ke 4 setelah terapi infus HSA 20\%, dengan tingkat kejadian tertinggi teramati pada hari ke-1 hingga minggu ke-1 (Tabel 2). Hasil penelitian Trow et al. (2008) melaporkan bahwa reaksi transfusi tertunda muncul pada 5-14 hari setelah pemberian infus albumin manusia yang meliputi kelemahan, edema, urtikaria, kepincangan, pireksia, lesi kulit yang mengindikasikan vaskulitis, vomitus, adanya rasa nyeri, dan penurunan nafsu makan. Hal serupa dilaporkan oleh Francis et al. (2007) bahwa terjadi reaksi transfusi tertunda yang terjadi berkisar antara 5-13 hari setelah infus HSA pada anjing.

Reaksi transfusi tertunda berupa lesi kulit dan urtikaria berkembang pada 1 dari 8 kucing setelah infus HSA 20\% dan terjadi pada satu ekor kucing. Lesi kulit dan urtikaria muncul pada hari ke-13 setelah infus has 20\% dan mulai membaik pada minggu ke- 6 dengan pemberian preparat diphenhydramine. Vigano et al. (2010) melaporkan bahwa reaksi transfusi tertunda pada hewan dikaitkan dengan respons terhadap infus HSA, yang puncaknya terjadi 4-6 minggu setelah terapi. Aplikasi HSA pada hewan masih menjadi kontroversi karena berpotensi menyebabkan reaksi hipersensitivitas parah sebagai akibat masuknya protein darah asing. Infus HSA memicu respons antibodi imunoglobulin $G(\operatorname{Ig} G)$ kuat pada hewan yang memuncak beberapa minggu setelah pemberian.

Pada penelitian ini, hewan tidak mengalami gangguan saat pemberian infus dan tidak ada pemberian obat untuk mengendalikan reaksi transfusi selama aplikasi infus HSA 20\% dilakukan.

Dari hasil penelitian ini dapat disimpulkan bahwa infus HSA 20\% dapat memicu reaksi transfusi segera maupun tertunda pada kucing hipoalbuminemia. Reaksi transfusi segera berupa peningkatan suhu rektal, aritmia jantung, ritme napas yang irreguler, tremor, dan kelemahan diamati terjadi mulai pada menit ke-15 hingga menit ke-120. Sementara itu, reaksi transfusi tertunda berupa penurunan nafsu makan, kelemahan, edema perifer, erithema, kepincangan, urtikaria, lesi kulit, diare, dan inflamasi intravaskuler diamati terjadi mulai pada hari ke-1 hingga minggu ke 4 setelah terapi infus human serum albumin $20 \%$. Kesembuhan pasien kucing bervariasi antara 1-5 minggu (7-35 hari). Satu ekor kucing masih mengalamai reaksi tertunda berupa urtikaria dan lesi kulit, namun setelah melewati satu bulan (30 hari) gejala tersebut mulai menghilang dan kucing dinyatakan sehat. Tidak ditemui adanya reaksi merugikan yang parah selama aplikasi terapi infus sehingga pemberian HSA 20\% dapat digunakan sebagai terapi suportif pada kasus hipoalbuminemia dan kompatibel terhadap kucing.

\section{UCAPAN TERIMA KASIH}

Ucapan terima kasih disampaikan kepada Kementerian Riset, Teknologi, dan Pendidikan Tinggi atas dana yang diberikan melalui Hibah Penelitian Terapan Unggulan Perguruan Tinggi untuk membantu pelaksaan penelitian ini. 
"Penulis menyatakan tidak ada konflik kepentingan dengan pihak-pihak yang terkait dalam penelitian ini".

\section{DAFTAR PUSTAKA}

Call D. 2005. The Use of Human Serum Albumin in Dogs. Veterinary Technician Journal 26: 1-5.

Chruszcz M, Mikolajczak K, Mank N, Majorek KA, Porebski PJ, Minor W. 2013. Serum Albumins Unusual Allergens. Biochimica et Biophysica Acta 1830: 5375-5381.

Cohn LA, Kerl ME, Lenox CE, Livingston RS, Dodam JR. 2007. Response of Healthy Dogs to Infusions of Human Serum Albumin. AJVR 68: 657-663.

Craft EM, Powell LL. 2012. The Use of Canine-spesific Albumin in Dogs with Septic Peritonitis. Journal of Veterinary Emergency and Critical Care 22: 631639.

Francis AH, Martin LG, Haldorson GJ, Lahmers KK, Luther TY, Alperin DC, Hines SA. 2007. Adverse Reactions Suggestive of Type III Hypersensitivity in Six Healthy Dogs Given Human Albumin. J Am Vet Med Assoc $230: 873-879$.

Gales BJ, Erstad BL. 1993. Adverse Reactions to Human Serum Albumin. Ann Pharmacother 27: 87-94.

Hackner SG. 2012. Plasma and Albumin Transfusion: Indications and Controversies. Cornell University Veterinary Specialists : 1-5.

He Y, Ning T, Xie T, Qiu Q, Zhang L, Sun Y, Jiang D, Fu K, Yin F, Zhang W, Shen L, Wang H, Li J, Lin Q, Sun Y, Li H, Zhu Y, Yang D. 2011. Large-scale Production of Functional Human Serum Albumin from Transgenic Rice Seeds. PNAS 108: 1907819083.

Horowitz FB, Read RL, Powell LL. 2015. A Retrospective Analysis of $25 \%$ Human Serum Albumin
Supplementation in Hypoalbuminemic Dogs with Septic Peritonitis. Can Vet J. 56: 591-597.

Mathews KA. 2008. The Therapeutic Use of $25 \%$ Human Serum Albumin in Critically III Dogs and Cats. Vet Clin Small Anim 38: 595-605.

Mazzaferro EM, Rudloff E, Kirby R. 2002. The Role of Albumin Replacement in the Critically III Veterinary Patient. Journal of Veterinary Emergency and Critical Care. 12: 113-124.

Powell C, Thompson L, Murtauqh RJ. 2013. Type III Hypersensitivity Reaction with Immune Complex Deposition in 2 Critically III Dogs Administered Human Serum Albumin. J Vet Emerg Crit Care. 23: 598-604.

Raoufinia R, Mota A, Keyhanvar N, Safari F, Shamekhi S, Abdolalizadeh J. 2016. Overview of Albumin and Its Purification Methods. Adv Pharm Bull. 6: 495-507.

Savigny M, Macintire DK. 2006. Human Albumin Therapy in Hypoalbuminemic in Dogs. Standards of Care: Emergency and Critical Care Medicine. 8: 7-11.

Throop JL, Kerl ME, Cohn LA. 2004. Albumin in Health and Disease: Cause and Treatment of Hypoalbuminemia. Compendium : 940-949

Triwibowo. 1996. Indikasi dan Reaksi Transfusi Darah. Peneribit Komite Medis RSUP. Dr. Sardjito. Yogyakarta. P53-75.

Trow AV, Rozanski EA, DeLaforcade AM, Chan DL. 2008. Evaluation of Use of Human Albumin in Critically III Dogs : 73 Cases (2003-2006). J Am Vet Med Assoc. 233: 607-612

Vigano F, Perissinotto L, Bosco VRF. 2010. Administration of $5 \%$ Human Serum Albumin in Critically III Small Animal Patients with Hypoalbuminemia: 418 Dogs and 170 Cats (1994-2008). Journal of Veterinary Emergency and Critical Care. 20: 237-243. 